\title{
Management of precocious puberty
}

\author{
Toshiaki Tanaka \\ From 7th APPES Biennial Scientific Meeting \\ Nusa Dua, Bali. 14-17 November 2012
}

The objectives of treatment for children with central precocious puberty (CPP) are to avoid psychosocial problems caused by early pubertal development and to normalize adult height (AH). A long-acting GnRH analog is the treatment of choice for CPP. GnRH analog administration effectively arrests further development of secondary sex characteristics, slows bone age (BA) maturation, increases pubertal height gain, and is believed to eventually improve $\mathrm{AH}$ prognosis. However, the improvement of $\mathrm{AH}$ is not well established. It is reported that GnRH analog is effective to improve adult height only in early onset (girls $<6$ years) CPP [1]. Although BA maturation is decelerated by suppressing gonadotropins with GnRH analog and pubertal period is elongated, growth rate diminishes due to suppressed sex steroid hormone and, in part due to decreased $\mathrm{GH}$ secretion.

For the evaluation of efficacy of GnRH analog for adult height improvement, one problem is that the prediction method for adult height in CPP is not established. It is reported that predicted adult height $(\mathrm{PAH})$ using the Bayley-Pinneau table for accelerated BA overestimated $\mathrm{AH}$ in untreated patients with $\mathrm{CPP}$, and the PAH based on the projected height SD score for BA is useful [2].

Most Asian countries use a starting dose of $100 \mu \mathrm{g} / \mathrm{kg} /$ month of leuproride acetate depo [3]. During GnRH ana$\log$ treatment, serum concentrations of $\mathrm{LH}$, testosterone or estradiol should be monitored as well as pubertal changes and bone age, height and height velocity. For some older patients, a dose of up to $180 \mu \mathrm{g} / \mathrm{kg} /$ month of leuproride acetate depo is necessary to suppress LH concentration less than $0.5 \mathrm{mIU} / \mathrm{ml}$. When growth velocity is decreased, possible options is to add growth hormone or anabolic steroid hormone only in boys.

The decision to stop therapy should be individualized and based on various factors such as growth velocity, bone age, chronological age, predicted adult height, emotional maturity, and patient's wish.

Tanaka Growth Clinic, Japan
After treatment discontinuation, long-term follow up is recommended for adult height, reproductive function and bone mineral density.

Published: 3 October 2013

\section{References}

1. Tanaka T, et al: Results of long-term follow-up after treatment of central precocious puberty with leuprorelin acetate: evaluation of effectiveness of treatment and recovery of gonadal function. J Clin Endocrinol Metab 2005, 90:1371-1376.

2. Kauli $R$, et al: Final height of girls with central precocious puberty, untreated versus treated with cyproterone acetate or GnRH analog. A comparative study with re-evaluation of prediction by the BayleyPinneau method. Horm Res 1997, 47:54-61.

3. Tanaka T, Lee PA: Treatment approaches for central precocious puberty in Asia and US: the role of gonadotropin-releasing hormone analog (GnRHa). Ped Endocrinol Rev 2008, 6(Suppl 1):259-262.

doi:10.1186/1687-9856-2013-S1-010

Cite this article as: Tanaka: Management of precocious puberty. International Journal of Pediatric Endocrinology 2013 2013(Suppl 1):010.
Submit your next manuscript to BioMed Central and take full advantage of:

- Convenient online submission

- Thorough peer review

- No space constraints or color figure charges

- Immediate publication on acceptance

- Inclusion in PubMed, CAS, Scopus and Google Scholar

- Research which is freely available for redistribution
() Bïomed Central
C Biomed Central

(c) 2013 Tanaka; licensee BioMed Central Ltd. This is an Open Access article distributed under the terms of the Creative Commons Attribution License (http://creativecommons.org/licenses/by/2.0), which permits unrestricted use, distribution, and reproduction in any medium, provided the original work is properly cited. 